\title{
The Pathologic Role of Toll-Like Receptor 4 in Prostate Cancer
}

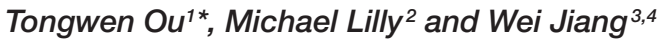 \\ 'Department of Urology, Xuanwu Hospital, Capital Medical University, Beijing, China, ${ }^{2}$ Division of Hematology and Oncology, \\ Department of Medicine, Medical University of South Carolina, Charleston, SC, United States, ${ }^{3}$ Department of Microbiology \\ and Immunology, Medical University of South Carolina, Charleston, SC, United States, ${ }^{4}$ Division of Infectious Diseases, \\ Department of Medicine, Medical University of South Carolina, Charleston, SC, United States
}

Toll-like receptor (TLR) 4 is expressed on normal and malignant prostate epithelial cells. The TLR4 and its downstream signaling pathways mediate innate immune responses in the host against invading pathogens. However, multiple lines of evidence shows that TLR4 expression is increased in prostate tissues from prostate cancer patients, and altered TLR4 signals may promote cancer development, as well as antitumor effects. In this review, we have summarized key features of the TLR4 signaling pathway and its associated immune responses and focused on the pathologic role of TLR4 in prostate carcinogenesis and tumor progression.

Keywords: toll-like receptor 4, prostate cancer, inflammation, carcinogens, bacteria

\section{OPEN ACCESS INTRODUCTION}

Edited by:

Anahid Jewett,

University of California, Los Angeles, United States

Reviewed by:

Alexandre Corthay, Oslo University Hospital, Norway

Constantinos Zambirinis, Memorial Sloan Kettering Cancer Center, United States

${ }^{*}$ Correspondence:

Tongwen Ou

outongwen@xwhosp.org

Specialty section: This article was submitted to Cancer Immunity and Immunotherapy, a section of the journal Frontiers in Immunology

Received: 05 January 2018 Accepted: 14 May 2018 Published: 06 June 2018

Citation: Ou T, Lilly M and Jiang W (2018) The Pathologic Role of Toll-Like Receptor 4 in Prostate Cancer.

Front. Immunol. 9:1188. doi: 10.3389/fimmu.2018.01188
Prostate cancer is one of the most common causes of morbidity and mortality in men. The prostate surrounds the upper part of the urethra. Retrograde translocation of bacteria from the urethra to the prostate may lead to chronic bacterial colonization of the prostate (1-4). Other possible points of entry of pathogenic organisms into the prostate may be through hematogenous and lymphatic dissemination from distant foci of infection (1-5). Indeed, infection and inflammation in the prostate are associated with increased risk of prostate cancer (6).

Infection and inflammation have been shown to associate with cancer development and progression. Colon cancer has a strong link with chronic inflammatory bowel diseases such as chronic ulcerative colitis and Crohn's disease (7). Gastric cancer associates with chronic Helicobacter pylori infection and its mediated inflammation (8). Other examples include papillomavirus infection and cervical cancer, hepatitis virus infection and liver cancer, ovarian endometriosis and epithelial ovarian cancers, bronchitis and lung cancer, schistosomiasis and bladder cancer, pancreatitis and pancreatic cancer, cholecystitis, and gallbladder cancer (9-11). Similarly, prostatitis is linked to prostate cancer (6).

Mechanistic studies on the role of inflammation have been investigated in some cancers. For example, colorectal cancer cells express toll-like receptor (TLR) 4 and myeloid differentiation factor (MD) 2 complex, and lipopolysaccharide (LPS) stimulation activates phosphatidylinositol 3'-kinase/ protein kinase $B(A K T)$ signaling pathway and promotes downstream betal integrin function through the TLR4/MD2 complex, resulting in increased adhesiveness and metastatic capacity of colorectal cancer cells (12). Greten et al. found mouse colitis-associated pro-inflammatory cytokines play a role in colorectal cancer development (13). In addition, TLR4-signaling engagement promotes the adhesiveness and metastatic capacity of colorectal cancer (12). Furthermore, inflammation through TLR4 signaling promotes the development of immune suppressive microenvironment, such as recruitment myeloid-derived suppressor cells into local tumor environment, in breast, colon, renal cell, and pancreatic cancers (14-18). But no such evidence has been shown in prostate cancer. Thus, decreased antitumor immunity in the local microenvironment may account for another mechanism in tumor cell activation, proliferation, survival, invasion, and tumor metastasis. However, inflammation 
and prostate cancer have not been extensively studied, and the mechanisms involved are not clear.

In this review, we focus on the pathologic role of TLR4 and its effects in prostate cancer development and progression. This is important for therapeutic strategy targeting TLR signaling or responsiveness (e.g., inhibitors for specific pro-inflammatory cytokine) to prevent prostate cancer development and progression.

\section{INFLAMMATION AND PROSTATE CANCER}

Inflammation is very common within the prostate, as there are about $10 \%$ male adults with prostatitis $(19,20)$. Several studies including a recent study found increased prostate cancer risk with a history of prostatitis and sexually transmitted diseases (relative risk $=1.30$ and $1.43 ; 95 \%$ confidence interval: $1.10-1.54$ and 1.07-1.91, respectively) (21). However, the mechanism of inflammation-mediated prostate cancer is unknown.

Proliferative inflammatory atrophy (PIA) is a precursor of prostatic intraepithelial neoplasia (PIN) and prostate cancer (22). Increased p53 immunostaining has been observed in PIA lesions, especially in the areas of acute inflammation (23). Studies from patients with bacterial prostatitis have revealed that several bacterial species induce inflammation and infect human prostate, and treatment with antibiotics results in a significant decrease in PSA levels, a marker for prostate cancer (24). E. coli and Enterococcus spp. are the most commonly bacteria found in bacterial prostatitis $(25,26)$. Upon stimulation, inflammatory cells infiltrate to the regions of prostatic atrophy and may contribute to the development of PIA, which contains regenerated atrophic epithelial cells in response to cell injury (22). Moreover, interaction and morphologic transitions between these lesions, PIA, PIN, and prostate cancer may contribute to cancer development and progression $(23,27)$. Notably, increased IL-6 and IL-6R expression has been observed in prostate cancer epithelial cells and high-grade PIN (28). Patients with metastatic prostate cancer have increased plasma IL-6 levels, which are correlated with PSA levels (29). These results suggest that inflammation such as bacterial infection, prostatitis, and pro-inflammatory cytokines (e.g., IL-6) may play a role in prostate cancer etiology and progression. Understanding the role of inflammation in prostate cancer development is critical as it has a great potential for therapeutic purposes.

\section{TLR4 SIGNALING PATHWAY}

Toll-like receptors recognize invading pathogens, initiate innate immune responses, and potentiate adaptive immune responses (30-32). There are 10 TLR family members that differ in their expression patterns and agonist specificities in humans (33). Peripheral monocytes, macrophages, and normal epithelial cells from skin, digestive, reproductive, and respiratory organs have been shown to express TLR4 (32-34). The TLR4 ligand LPS is a major component of Gram-negative bacterial outer membranes (35). LPS triggers the TLR4 cell signaling pathway through initial binding to the LPS-binding protein and CD14, and subsequently to the TLR4/MD2 complex (36). Activation of the TLR4/MD2 complex results in conformational changes that enable downstream signal transduction (36).
Toll-like receptor 4 endogenous ligands [e.g., heat shock proteins (HSPs), fibrinogen, and high mobility group box 1 (HMGB1)] have been reported not only to initiate innate immune responses but also to function as danger-associated molecular patterns (37-39). Fibrinogen is mainly synthesized by hepatocytes; thrombin promotes fibrinogen to convert to fibrin and fibrinogen cleavage products, which function as TLR4 ligands and activate macrophages to produce inflammatory cytokines (40). Another endogenous TLR4 agonists, HSPs play a role in protein folding which directly bind to TLR4 on cell surface and activate dendritic cells through MAPK and NF- $\mathrm{\kappa B}$ pathways, resulting in the production of pro-inflammatory cytokines (e.g., TNF- $\alpha$, IL- $1 \beta$, and IL-12p70) (41). Moreover, HMGB1 is a DNA-binding protein and plays a key role in the induction of inflammation after injury through TLR4/MD2 complex (42).

The TLR4 signaling pathway has been extensively studied. Ligation of TLR4 complex triggers two distinct cell signaling pathways (Figure 1) - myeloid differentiation factor 88 (MyD88)dependent pathway and MyD88-independent pathway. In the MyD88-dependent pathway, upon the activation of MyD88, IL-1 receptor-associated kinase and tumor necrosis factor-receptorassociated factor 6 (TRAF6) are recruited to induce activation of the inhibitor of $\kappa \mathrm{B}(\mathrm{I} \kappa \mathrm{B})$ complex (IKK) and I $\mathrm{B} \alpha$ degradation, which results in the subsequent activation and nuclear translocation of NF- $\mathrm{KB}$ and pro-inflammatory cytokine production (e.g., TNF- $\alpha$ and IL-6) (43). Moreover, other cell signaling pathways

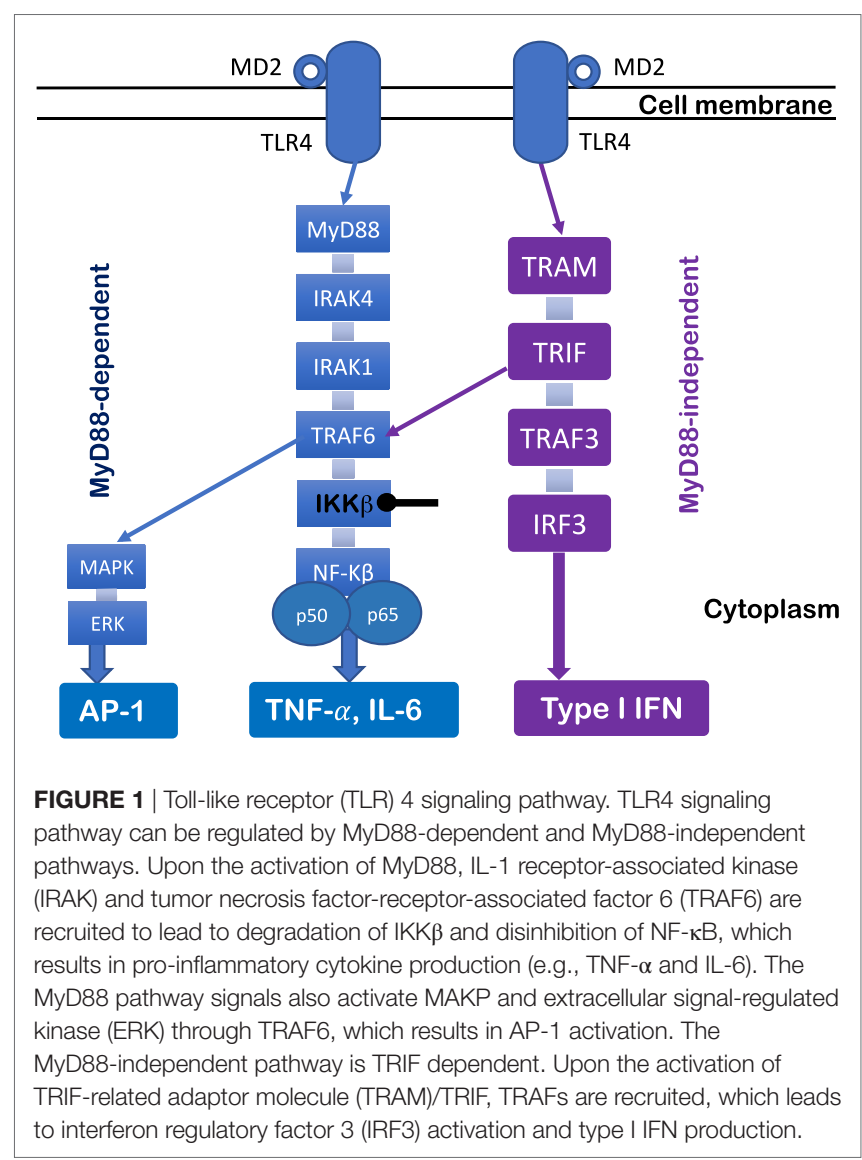


also are involved in TLR4 signaling pathway [e.g., Jun N-terminal Kinase (JNK), p38, and extracellular signal-regulated kinase 1/2]. For example, the activation of TRAF6 further induces transforming growth factor- $\beta$-activated protein kinase 1 activation, resulting in the activation of members of the MAP kinase 3 (MKK3) and MKK6 which eventually activate pathways that phosphorylate JNK and p38 (43). Moreover, the MyD88-independent pathway is TIR-domain-containing adapter-inducing interferon- $\beta$ (TRIF) dependent. Upon the activation of TRIF-related adaptor molecule/ TRIF, TRAFs are recruited, and interferon regulatory factor 3 is activated, which leads to type I IFN production (Figure 1). Therefore, the activation of these cell signaling pathways after TLR4 engagement results in gene transcription and a cascade of inflammatory responses that initiate antimicrobial responses at the site of infection or inflammation (43).

\section{TLR4 RESPONSES AND PROSTATE CANCER}

Toll-like receptor ligands have great potential as anticancer agents due to their adjuvant effects for adaptive immunity (44). Administration of TLR ligands in infrequent and high doses may act as immunologic adjuvants (44). On the other hand, low or physiologic doses of TLR agonists may mediate cancer development $(5,10)$, as evidenced by the use of TLR inhibitors to treat certain cancers $(10,45)$. TLR4 expression and its attendant chronic inflammation (e.g., IL-6) are associated with faster progression and poorer treatment outcomes in prostate cancer $(5,11,44,46,47)$. Functional TLRs are expressed on a wide variety of cancer cells $(10,48)$ and may contribute to oncogenesis $(10,49-51)$. Chronic inflammation may result from infections and exposure to bacterial products (e.g., TLR agonists), and contribute to prostate carcinogenesis (11). However, in many patients, a source of chronic infection and inflammation is not apparent.

Toll-like receptor 4 stimulation through microbial molecules (e.g., LPS), as well as endogenous ligands (e.g., HSPs, fibrinogen, and HMGB1), induces pro-inflammatory cytokine production, such as IL-6, TGF- $\beta 1$, TNF- $\alpha$, IL- $1 \beta$, inducible nitric oxide synthase, and antiapoptotic protein expression $(40-42,51)$. Notably, TLR4 is expressed on normal and malignant prostate epithelial cells $(32,47)$. Activation of TLR4 signaling in prostate cells initiates innate immune responses to invading pathogens. However, long-term activation of TLR4 cell signaling pathway in prostate epithelial cells may promote tumor cell activation, proliferation, survival, and tumor transformation $(5,47,52)$. The microbial products lipoteichoic acid and LPS from oral pathogenic bacteria facilitate oncogenic herpesvirus infection in primary oral cells (53). In addition, TLR downstream cytokines IL-6, IL-8, and IL-10 mediate prostate cancer development and disease progression (54-57). Moreover, upon TLR4 ligand stimulation, prostate epithelial cells upregulate NF- $\mathrm{B}$, TGF- $\beta 1$, and VEGF through increased TLR4 expression and induction of pro-inflammatory mediators $(47,58)$. Higher levels of some TLR4 downstream cytokines (e.g., IL-8) have been observed in prostate cancer tissues compared with control non-tumor tissues (59), suggesting that prostate cells experience persistent elevated inflammation presumably in response to bacterial products such as LPS as well as endogenous TLR4 ligands released from injured cells.

Immune suppressive microenvironment has been reported for other cancers except prostate cancer (14-18). We hypothesize that persistent bacterial LPS stimulation from bacterial colonization of the prostate may promote the development of immune suppressive microenvironment, including generation of $\mathrm{T}$ regulatory cells and tumor-associated macrophages and recruitment of myeloid-derived suppressor cells into local prostate tumor environment through TLR4 signaling. We hypothesize that these changes may result in decreased antitumor immunity and transformation from non-cancer prostate cells to prostate cancer cells. In addition, we hypothesize that long-term stimulation through TLR4 signaling in prostate cancer may lead to altered TLR4 responsiveness in tumor microenvironment. There is evidence on the role of increased plasma levels of fibrinogen and endogenous TLR4 ligands in breast cancer cell proliferation, survival, metastasis of cancer cells, and prognosis in patients $(60,61)$, however, their roles in prostate cancer are unclear. Whether systemic levels of TLR4 ligands (e.g., LPS, fibrinogen, and HSPs) are apparent in prostate cancer remains unknown. However, increased TLR4 expression and increased TLR4 responsiveness have been observed in prostate cancer cells $(47,58)$. Furthermore, TLR4 stimulation may have indirect effects on promoting prostate cancer development through reducing immune function in the tumor microenvironment $(62,63)$.

Knockout of TLR4 in PC3 prostate cancer cells decreases tumor cell migration and invasion (64). A TLR4 gene single nucleotide polymorphism may be associated with the risk of prostate cancer though results are not consistent $(46,65,66)$. Peroxiredoxin- 1 , a TLR4 ligand, has been shown to interact with TLR4 to promote prostate tumor cell growth through chronic activation of cancer angiogenesis in a murine cancer model (67). Thus, TLR4-related innate immune activation and inflammation may play a role in the etiology and progression of prostate cancer $(68,69)$.

Toll-like receptor 4 may also contribute to the development of other cancers besides prostate cancer, including, but not limited to, liver cancer, reproductive organ cancer, pancreatic cancer, intestinal cancer, and skin cancer $(45,70,71)$. For example, the knockdown of MyD88 results in a failure of ovarian cancer cell proliferation and cytokine production in response to LPS (50), suggesting that TLR4-MyD88 cell signaling contributes to epithelial ovarian cancer growth (50). Moreover, TLR4 ligands promote

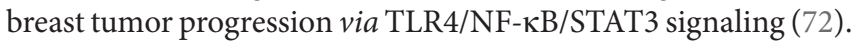
The anti-inflammatory compound andrographolide suppresses human colon cancer cell proliferation through the TLR4/NF- $\mathrm{BB} /$ matrix metalloproteinase-9 signaling pathway (73).

\section{ANTIBACTERIAL AND ANTI- INFLAMMATORY TREATMENT ON PROSTATE CANCER}

Recent advances in antibacterial and anti-inflammatory treatment on prostate cancer provide some information on the role of TLR activation in prostate cancer.

Gene silencing of TLR4 using small interfering RNA (siRNA) in PC3 cells significantly inhibits tumor cell migration and invasion, 
reduces cell viability, and mediates cell death (64). These effects are achieved by reducing expression (MyD88) or phosphorylation (TRIF, IRF-1) of TLR4 signaling pathway downstream-related molecules (64). Moreover, in a mouse prostate cancer model, TLR4 siRNA administration inhibits tumor growth and survival (64). These results suggest that TLR4 contributes to prostate cancer oncogenesis and progression (64). Furthermore, inhibition of LPS-mediated activation of TLR4 signaling pathway by selenium in human PCs cells results in decreased pro-inflammatory and likely anticancer activities (74).

Isothiocyanates, products from glucosinolates in plants, have anti-inflammatory, antiviral, and antibacterial properties. 3-Methylsulfinylpropyl isothiocyanate is shown to disrupt dimerization of the TLRs via covalent binding and thus has anti-inflammatory and TLR inhibitory activities (75). Moreover, phenethyl isothiocyanate inhibits TLR cell signaling pathway through interferon regulatory factor, which results in decreased IP-10 production in response to LPS (76). Furthermore, isothiocyanates induces cell apoptosis and cell cycle arrest, downregulates cell activation, and modulates epigenetic genes in PC3 cells, thus has anticancer activities (77-80).

\section{ANTITUMOR ACTIVITY OF TLR4}

Mutation of TLR4 has been shown to result in susceptibility to infection by Gram-negative bacteria (81). TLR4 responses have been shown to confer antitumor activity. Recognition of TLR4 on antigen-presenting cells is able to enhance antigen-specific antitumor immunity $(82,83)$, therefore TLR4 agonists have been tested as antitumor therapy (84). We hypothesize that long-term low doses of microbial or endogenous TLR4 ligand simulation in local microenvironments (e.g., prostate) may promote cancer development; whereas one or two-time administration with high doses of TLR4 ligands (e.g., vaccine adjuvant) enhance antigenspecific antitumor immune responses. Further studies are needed to determine the mechanism involved for the contradictory effects of TLR4 on cancer.

\section{THE ROLE OF OTHER TLRS IN PROSTATE CANCER}

Toll-like receptor 9 has been shown to promote prostate cancer progression. Hossain et al. have shown that myeloid-derived suppressor

\section{REFERENCES}

1. Lopatin WB, Martynik M, Hickey DP, Vivas C, Hakala TR. Retrograde transurethral balloon dilation of prostate: innovative management of abacterial chronic prostatitis and prostatodynia. Urology (1990) 36(6):508-10. doi:10.1016/0090-4295(90)80188-S

2. Morgan MG, Nally C, Hickey D, Murphy DM. Urethral and prostatic colonization and infection in patients undergoing prostatectomy. J Hosp Infect (1988) 12(3):199-206. doi:10.1016/0195-6701(88)90007-2

3. Norlen LJ, Blaivas JG. Unsuspected proximal urethral obstruction in young and middle-aged men. J Urol (1986) 135(5):972-6. doi:10.1016/ S0022-5347(17)45942-8

4. Drach GW. Sexuality and prostatitis: a hypothesis. J Am Vener Dis Assoc (1976) 3(2 Pt 1):87-8. cells express TLR9, accumulate in the circulation in patients with metastatic prostate cancer, and inhibit effector CD8+ T cell activity (85). Another study has determined that engraftment of TLR9expressing prostate cells into mice results in the cross talk between TLR9 and leukemia inhibitory factor and promotes immunosuppressive activity through STATs and PMN-MDSCs (86). Moreover, TLR9 has been shown to be essential for propagation and selfrenewal of prostate cancer cells through NF- $\mathrm{KB} /$ RELA and STAT3 pathways, and TLR9-positive tumors have a unique gene profile that associate with inflammation and stem cells (87). Importantly, TLR9 cytoplasmic immunostaining is positive in the majority of patients (66.7\% strongly and $31.7 \%$ weakly positive) in prostate cancer cells (88). Although TLR9 expression is not associated with most markers of disease pathogenesis and progression (e.g., pT-class, Gleason score, and preoperative PSA level); it is associated with prostate cancer-specific progression-free survival in prostate cancer patients who have been treated by radical prostatectomy with curative intent (88). These results imply a pathologic role of TLR9 in prostate cancer progression. Targeting TLR9 signaling may provide therapeutic strategies for prostate cancer patients.

\section{CONCLUSION}

In this review, we have summarized and discussed studies in TLR4 and prostate cancer and emphasized on the pathologic role of TLR4 in prostate cancer oncogenesis. This provides some insights about TLR4 inhibitors as potential prevention strategies for prostate cancer.

\section{AUTHOR CONTRIBUTIONS}

WJ wrote the first version of manuscript. ML and TO revised the manuscript.

\section{FUNDING}

This work is supported by the National Institute of Allergy and Infectious Diseases grant AI091526 (WJ) and AI1288864 (WJ), the DOD/CDMRP Prostate Cancer Research Program grant W81XWH-15-1-0696 (ML), and by pilot research funding from an American Cancer Society Institutional Research Grant awarded to the Hollings Cancer Center, Medical University of South Carolina (WJ).

5. Kundu SD, Lee C, Billips BK, Habermacher GM, Zhang Q, Liu V, et al. The toll-like receptor pathway: a novel mechanism of infection-induced carcinogenesis of prostate epithelial cells. Prostate (2008) 68(2):223-9. doi:10.1002/ pros. 20710

6. Sfanos KS, De Marzo AM. Prostate cancer and inflammation: the evidence. Histopathology (2012) 60(1):199-215. doi:10.1111/j.1365-2559. 2011.04033.x

7. Balkwill F, Coussens LM. Cancer: an inflammatory link. Nature (2004) 431(7007):405-6. doi:10.1038/431405a

8. Ernst PB, Takaishi H, Crowe SE. Helicobacter pylori infection as a model for gastrointestinal immunity and chronic inflammatory diseases. Dig Dis (2001) 19(2):104-11. doi:10.1159/000050663

9. Sekizawa A, Amemiya S, Otsuka J, Saito H, Farina A, Okai T, et al. Malignant transformation of endometriosis: application of laser microdissection 
for analysis of genetic alterations according to pathological changes. Med Electron Microsc (2004) 37(2):97-100. doi:10.1007/s00795-003-0233-0

10. Chen R, Alvero AB, Silasi DA, Steffensen KD, Mor G. Cancers take their toll - the function and regulation of toll-like receptors in cancer cells. Oncogene (2008) 27(2):225-33. doi:10.1038/sj.onc.1210907

11. Coussens LM, Werb Z. Inflammation and cancer. Nature (2002) 420(6917): 860-7. doi:10.1038/nature01322

12. Hsu RY, Chan CH, Spicer JD, Rousseau MC, Giannias B, Rousseau S, et al. LPS-induced TLR4 signaling in human colorectal cancer cells increases beta1 integrin-mediated cell adhesion and liver metastasis. Cancer Res (2011) 71(5):1989-98. doi:10.1158/0008-5472.CAN-10-2833

13. Greten FR, Eckmann L, Greten TF, Park JM, Li ZW, Egan LJ, et al. IKKbeta links inflammation and tumorigenesis in a mouse model of colitis-associated cancer. Cell (2004) 118(3):285-96. doi:10.1016/j.cell.2004.07.013

14. Almand B, Clark JI, Nikitina E, van Beynen J, English NR, Knight SC, et al. Increased production of immature myeloid cells in cancer patients: a mechanism of immunosuppression in cancer. J Immunol (2001) 166(1):678-89. doi:10.4049/jimmunol.166.1.678

15. Zea AH, Rodriguez PC, Atkins MB, Hernandez C, Signoretti S, Zabaleta J, et al. Arginase-producing myeloid suppressor cells in renal cell carcinoma patients: a mechanism of tumor evasion. Cancer Res (2005) 65(8):3044-8. doi:10.1158/0008-5472.CAN-04-4505

16. Srivastava MK, Bosch JJ, Thompson JA, Ksander BR, Edelman MJ, Ostrand-Rosenberg S. Lung cancer patients' CD4(+) T cells are activated in vitro by MHC II cell-based vaccines despite the presence of myeloidderived suppressor cells. Cancer Immunol Immunother (2008) 57(10): 1493-504. doi:10.1007/s00262-008-0490-9

17. Gabitass RF, Annels NE, Stocken DD, Pandha HA, Middleton GW. Elevated myeloid-derived suppressor cells in pancreatic, esophageal and gastric cancer are an independent prognostic factor and are associated with significant elevation of the Th2 cytokine interleukin-13. Cancer Immunol Immunother (2011) 60(10):1419-30. doi:10.1007/s00262-011-1028-0

18. Rodriguez PC, Ernstoff MS, Hernandez C, Atkins M, Zabaleta J, Sierra R, et al. Arginase I-producing myeloid-derived suppressor cells in renal cell carcinoma are a subpopulation of activated granulocytes. Cancer Res (2009) 69(4):1553-60. doi:10.1158/0008-5472.CAN-08-1921

19. Collins MM, Meigs JB, Barry MJ, Walker Corkery E, Giovannucci E, Kawachi I. Prevalence and correlates of prostatitis in the health professionals follow-up study cohort. J Urol (2002) 167(3):1363-6. doi:10.1097/00005392-20020300000036

20. Adamczyk P, Wolski Z, Butkiewicz R, Nussbeutel J, Drewa T. Inflammatory changes in biopsy specimens from patients with suspected prostate cancer. Cent European J Urol (2013) 66(3):256-62. doi:10.5173/ceju.2013. 03.art2

21. Cheng I, Witte JS, Jacobsen SJ, Haque R, Quinn VP, Quesenberry CP, et al. Prostatitis, sexually transmitted diseases, and prostate cancer: the California Men's Health Study. PLoS One (2010) 5(1):e8736. doi:10.1371/journal. pone. 0008736

22. De Marzo AM, Marchi VL, Epstein JI, Nelson WG. Proliferative inflammatory atrophy of the prostate: implications for prostatic carcinogenesis. Am J Pathol (1999) 155(6):1985-92. doi:10.1016/S0002-9440(10)65517-4

23. Wang W, Bergh A, Damber JE. Increased p53 immunoreactivity in proliferative inflammatory atrophy of prostate is related to focal acute inflammation. APMIS (2009) 117(3):185-95. doi:10.1111/j.1600-0463.2008. 00006.x

24. Ugurlu O, Yaris M, Oztekin CV, Kosan TM, Adsan O, Cetinkaya M. Impacts of antibiotic and anti-inflammatory therapies on serum prostate-specific antigen levels in the presence of prostatic inflammation: a prospective randomized controlled trial. Urol Int (2010) 84(2):185-90. doi:10.1159/000277596

25. Brede CM, Shoskes DA. The etiology and management of acute prostatitis. Nat Rev Urol (2011) 8(4):207-12. doi:10.1038/nrurol.2011.22

26. Sfanos KS, Sauvageot J, Fedor HL, Dick JD, De Marzo AM, Isaacs WB. A molecular analysis of prokaryotic and viral DNA sequences in prostate tissue from patients with prostate cancer indicates the presence of multiple and diverse microorganisms. Prostate (2008) 68(3):306-20. doi:10.1002/ pros. 20680

27. Putzi MJ, De Marzo AM. Morphologic transitions between proliferative inflammatory atrophy and high-grade prostatic intraepithelial neoplasia. Urology (2000) 56(5):828-32. doi:10.1016/S0090-4295(00)00776-7
28. Hobisch A, Rogatsch H, Hittmair A, Fuchs D, Bartsch G Jr, Klocker H, et al. Immunohistochemical localization of interleukin-6 and its receptor in benign, premalignant and malignant prostate tissue. J Pathol (2000) 191(3):239-44. doi:10.1002/1096-9896(2000)9999:9999<::AID-PATH633>3.0.CO;2-X

29. Adler HL, McCurdy MA, Kattan MW, Timme TL, Scardino PT, Thompson TC. Elevated levels of circulating interleukin-6 and transforming growth factor-beta1 in patients with metastatic prostatic carcinoma. J Urol (1999) 161(1):182-7. doi:10.1016/S0022-5347(01)62092-5

30. Akira S, Takeda K, Kaisho T. Toll-like receptors: critical proteins linking innate and acquired immunity. Nat Immunol (2001) 2(8):675-80. doi:10.1038/90609

31. Medzhitov R. Toll-like receptors and innate immunity. Nat Rev Immunol (2001) 1(2):135-45. doi:10.1038/35100529

32. Nishimura M, Naito $S$. Tissue-specific mRNA expression profiles of human toll-like receptors and related genes. Biol Pharm Bull (2005) 28(5):886-92. doi:10.1248/bpb.28.886

33. Hornung V, Rothenfusser S, Britsch S, Krug A, Jahrsdorfer B, Giese T, et al. Quantitative expression of toll-like receptor 1-10 mRNA in cellular subsets of human peripheral blood mononuclear cells and sensitivity to CpG oligodeoxynucleotides. J Immunol (2002) 168(9):4531-7. doi:10.4049/ jimmunol.168.9.4531

34. Chen YC, Giovannucci E, Lazarus R, Kraft P, Ketkar S, Hunter DJ. Sequence variants of Toll-like receptor 4 and susceptibility to prostate cancer. Cancer Res (2005) 65(24):11771-8. doi:10.1158/0008-5472.CAN-05-2078

35. Alexander C, Rietschel ET. Bacterial lipopolysaccharides and innate immunity. J Endotoxin Res (2001) 7(3):167-202. doi:10.1177/09680519010070 030101

36. Malm J, Nordahl EA, Bjartell A, Sorensen OE, Frohm B, Dentener MA, et al. Lipopolysaccharide-binding protein is produced in the epididymis and associated with spermatozoa and prostasomes. J Reprod Immunol (2005) 66(1):33-43. doi:10.1016/j.jri.2005.01.005

37. Smiley ST, King JA, Hancock WW. Fibrinogen stimulates macrophage chemokine secretion through toll-like receptor 4. J Immunol (2001) 167(5):2887-94. doi:10.4049/jimmunol.167.5.2887

38. Apetoh L, Ghiringhelli F, Tesniere A, Obeid M, Ortiz C, Criollo A, et al. Toll-like receptor 4-dependent contribution of the immune system to anticancer chemotherapy and radiotherapy. Nat Med (2007) 13(9):1050-9. doi: $10.1038 / \mathrm{nm} 1622$

39. Dybdahl B, Wahba A, Lien E, Flo TH, Waage A, Qureshi N, et al. Inflammatory response after open heart surgery: release of heat-shock protein 70 and signaling through toll-like receptor-4. Circulation (2002) 105(6):685-90. doi:10.1161/hc0602.103617

40. Millien VO, Lu W, Shaw J, Yuan X, Mak G, Roberts L, et al. Cleavage of fibrinogen by proteinases elicits allergic responses through toll-like receptor 4 . Science (2013) 341(6147):792-6. doi:10.1126/science.1240342

41. Fang $\mathrm{H}, \mathrm{Wu} \mathrm{Y}$, Huang X, Wang W, Ang B, Cao X, et al. Toll-like receptor 4 (TLR4) is essential for Hsp70-like protein 1 (HSP70L1) to activate dendritic cells and induce Th1 response. J Biol Chem (2011) 286(35):30393-400. doi:10.1074/jbc.M111.266528

42. Kim S, Kim SY, Pribis JP, Lotze M, Mollen KP, Shapiro R, et al. Signaling of high mobility group box 1 (HMGB1) through toll-like receptor 4 in macrophages requires CD14. Mol Med (2013) 19:88-98. doi:10.2119/molmed.2012. 00306

43. Kawasaki T, Kawai T. Toll-like receptor signaling pathways. Front Immunol (2014) 5:461. doi:10.3389/fimmu.2014.00461

44. Gambara G, De Cesaris P, De Nunzio C, Ziparo E, Tubaro A, Filippini A, et al. Toll-like receptors in prostate infection and cancer between bench and bedside. J Cell Mol Med (2013) 17(6):713-22. doi:10.1111/jcmm.12055

45. Rakoff-Nahoum S, Medzhitov R. Toll-like receptors and cancer. Nat Rev Cancer (2009) 9(1):57-63. doi:10.1038/nrc2541

46. Cheng I, Plummer SJ, Casey G, Witte JS. Toll-like receptor 4 genetic variation and advanced prostate cancer risk. Cancer Epidemiol Biomarkers Prev (2007) 16(2):352-5. doi:10.1158/1055-9965.EPI-07-0165

47. Gonzalez-Reyes S, Fernandez JM, Gonzalez LO, Aguirre A, Suarez A, Gonzalez JM, et al. Study of TLR3, TLR4, and TLR9 in prostate carcinomas and their association with biochemical recurrence. Cancer Immunol Immunother (2011) 60(2):217-26. doi:10.1007/s00262-010-0931-0

48. Yu L, Chen S. Toll-like receptors expressed in tumor cells: targets for therapy. Cancer Immunol Immunother (2008) 57(9):1271-8. doi:10.1007/ s00262-008-0459-8 
49. Salaun B, Coste I, Rissoan MC, Lebecque SJ, Renno T. TLR3 can directly trigger apoptosis in human cancer cells. J Immunol (2006) 176(8):4894-901. doi:10.4049/jimmunol.176.8.4894

50. Kelly MG, Alvero AB, Chen R, Silasi DA, Abrahams VM, Chan S, et al. TLR-4 signaling promotes tumor growth and paclitaxel chemoresistance in ovarian cancer. Cancer Res (2006) 66(7):3859-68. doi:10.1158/0008-5472. CAN-05-3948

51. Huang B, Zhao J, Li H, He KL, Chen Y, Chen SH, et al. Toll-like receptors on tumor cells facilitate evasion of immune surveillance. Cancer Res (2005) 65(12):5009-14. doi:10.1158/0008-5472.CAN-05-0784

52. Fukata M, Abreu MT. Pathogen recognition receptors, cancer and inflammation in the gut. Curr Opin Pharmacol (2009) 9(6):680-7. doi:10.1016/ j.coph.2009.09.006

53. Dai L, DeFee MR, Cao Y, Wen J, Wen X, Noverr MC, et al. Lipoteichoic acid (LTA) and lipopolysaccharides (LPS) from periodontal pathogenic bacteria facilitate oncogenic herpesvirus infection within primary oral cells. PLoS One (2014) 9(6):e101326. doi:10.1371/journal.pone.0101326

54. Pierce BL, Biggs ML, DeCambre M, Reiner AP, Li C, Fitzpatrick A, et al. C-reactive protein, interleukin-6, and prostate cancer risk in men aged 65 years and older. Cancer Causes Control (2009) 20(7):1193-203. doi:10.1007/ s10552-009-9320-4

55. Vijayakumar S, Henegan JC, Zhang X, Wang W, Day WA, Vijayakumar V, et al. Enriching gene expression profiles will help personalize prostate cancer management for African-Americans: a perspective. Urol Oncol (2017) 35(6):315-21. doi:10.1016/j.urolonc.2017.04.003

56. Hardiman G, Savage SJ, Hazard ES, Wilson RC, Courtney SM, Smith MT, et al. Systems analysis of the prostate transcriptome in African-American men compared with European-American men. Pharmacogenomics (2016) 17(10):1129-43. doi:10.2217/pgs-2016-0025

57. De Nunzio C, Kramer G, Marberger M, Montironi R, Nelson W, Schroder F, et al. The controversial relationship between benign prostatic hyperplasia and prostate cancer: the role of inflammation. Eur Urol (2011) 60(1):106-17. doi:10.1016/j.eururo.2011.03.055

58. Gatti G, Rivero V, Motrich RD, Maccioni M. Prostate epithelial cells can act as early sensors of infection by up-regulating TLR4 expression and proinflammatory mediators upon LPS stimulation. J Leukoc Biol (2006) 79(5):989-98. doi:10.1189/jlb.1005597

59. Hochreiter WW, Nadler RB, Koch AE, Campbell PL, Ludwig M, Weidner W, et al. Evaluation of the cytokines interleukin 8 and epithelial neutrophil activating peptide 78 as indicators of inflammation in prostatic secretions. Urology (2000) 56(6):1025-9. doi:10.1016/S0090-4295(00)00844-X

60. Wen J, Yang Y, Ye F, Huang X, Li S, Wang Q, et al. The preoperative plasma fibrinogen level is an independent prognostic factor for overall survival of breast cancer patients who underwent surgical treatment. Breast (2015) 24(6):745-50. doi:10.1016/j.breast.2015.09.007

61. Saini J, Sharma PK. Clinical, prognostic and therapeutic significance of heat shock proteins in cancer. Curr Drug Targets (2017). doi:10.2174/1389450118 666170823121248

62. Engblom C, Pfirschke C, Pittet MJ. The role of myeloid cells in cancer therapies. Nat Rev Cancer (2016) 16(7):447-62. doi:10.1038/nrc.2016.54

63. Ugel S, De Sanctis F, Mandruzzato S, Bronte V. Tumor-induced myeloid deviation: when myeloid-derived suppressor cells meet tumor-associated macrophages. J Clin Invest (2015) 125(9):3365-76. doi:10.1172/JCI80006

64. Hua D, Liu MY, Cheng ZD, Qin XJ, Zhang HM, Chen Y, et al. Small interfering RNA-directed targeting of toll-like receptor 4 inhibits human prostate cancer cell invasion, survival, and tumorigenicity. Mol Immunol (2009) 46(15):2876-84. doi:10.1016/j.molimm.2009.06.016

65. Vidas Z. Polymorphisms in toll-like receptor genes - implications for prostate cancer development. Coll Antropol (2010) 34(2):779-83.

66. Zheng SL, Augustsson-Balter K, Chang B, Hedelin M, Li L, Adami HO, et al. Sequence variants of toll-like receptor 4 are associated with prostate cancer risk: results from the cancer prostate in Sweden study. Cancer Res (2004) 64(8):2918-22. doi:10.1158/0008-5472.CAN-03-3280

67. RiddellJR, Maier P, Sass SN, Moser MT, Foster BA, Gollnick SO. Peroxiredoxin 1 stimulates endothelial cell expression of VEGF via TLR4 dependent activation of HIF-1alpha. PLoS One (2012) 7(11):e50394. doi:10.1371/journal. pone.0050394
68. Kazma R, Mefford JA, Cheng I, Plummer SJ, Levin AM, Rybicki BA, et al. Association of the innate immunity and inflammation pathway with advanced prostate cancer risk. PLoS One (2012) 7(12):e51680. doi:10.1371/journal. pone. 0051680

69. Mason TE, Ricks-Santi L, Chen W, Apprey V, Joykutty J, Ahaghotu C, et al. Association of CD14 variant with prostate cancer in African American men. Prostate (2010) 70(3):262-9. doi:10.1002/pros.21060

70. Mai CW, Kang YB, Pichika MR. Should a toll-like receptor 4 (TLR-4) agonist or antagonist be designed to treat cancer? TLR-4: its expression and effects in the ten most common cancers. Onco Targets Ther (2013) 6:1573-87. doi:10.2147/OTT.S50838

71. Ochi A, Nguyen AH, Bedrosian AS, Mushlin HM, Zarbakhsh S, Barilla R, et al. MyD88 inhibition amplifies dendritic cell capacity to promote pancreatic carcinogenesis via Th2 cells. J Exp Med (2012) 209(9):1671-87. doi:10.1084/ jem.20111706

72. Wang CH, Wang PJ, Hsieh YC, Lo S, Lee YC, Chen YC, et al. Resistin facilitates breast cancer progression via TLR4-mediated induction of mesenchymal phenotypes and stemness properties. Oncogene (2018) 37(5):589-600. doi:10.1038/onc.2017.357

73. Zhang R, Zhao J, Xu J, Jiao DX, Wang J, Gong ZQ, et al. Andrographolide suppresses proliferation of human colon cancer SW620 cells through the TLR4/NF-kappaB/MMP-9 signaling pathway. Oncol Lett (2017) 14(4): 4305-10. doi:10.3892/ol.2017.6669

74. Pei Z, Li H, Guo Y, Jin Y, Lin D. Sodium selenite inhibits the expression of VEGF, TGFbeta(1) and IL-6 induced by LPS in human PC3 cells via TLR4NF-(K)B signaling blockage. Int Immunopharmacol (2010) 10(1):50-6. doi:10.1016/j.intimp.2009.09.020

75. Shibata T, Nakashima F, Honda K, Lu YJ, Kondo T, Ushida Y, et al. Toll-like receptors as a target of food-derived anti-inflammatory compounds. J Biol Chem (2014) 289(47):32757-72. doi:10.1074/jbc.M114.585901

76. Park HJ, Kim SJ, Park SJ, Eom SH, Gu GJ, Kim SH, et al. Phenethyl isothiocyanate regulates inflammation through suppression of the TRIF-dependent signaling pathway of toll-like receptors. Life Sci (2013) 92(13):793-8. doi:10.1016/j.lfs.2013.02.012

77. Talalay P, Fahey JW. Phytochemicals from cruciferous plants protect against cancer by modulating carcinogen metabolism. J Nutr (2001) 131(11 Suppl): 3027S-33S. doi:10.1093/jn/131.11.3027S

78. Wattenberg LW. Inhibition of carcinogenic effects of polycyclic hydrocarbons by benzyl isothiocyanate and related compounds. J Natl Cancer Inst (1977) 58(2):395-8. doi:10.1093/jnci/58.2.395

79. Gupta P, Srivastava SK. Antitumor activity of phenethyl isothiocyanate in HER2-positive breast cancer models. BMC Med (2012) 10:80. doi:10.1186/ 1741-7015-10-80

80. Singh SV, Singh K. Cancer chemoprevention with dietary isothiocyanates mature for clinical translational research. Carcinogenesis (2012) 33(10): 1833-42. doi:10.1093/carcin/bgs216

81. Poltorak A, He X, Smirnova I, Liu MY, Van Huffel C, Du X, et al. Defective LPS signaling in $\mathrm{C} 3 \mathrm{H} / \mathrm{HeJ}$ and $\mathrm{C} 57 \mathrm{BL} / 10 \mathrm{ScCr}$ mice: mutations in Tlr4 gene. Science (1998) 282(5396):2085-8. doi:10.1126/science.282. 5396.2085

82. Fang $\mathrm{H}$, Ang B, Xu X, Huang $\mathrm{X}$, Wu Y, Sun $\mathrm{Y}$, et al. TLR4 is essential for dendritic cell activation and anti-tumor T-cell response enhancement by DAMPs released from chemically stressed cancer cells. Cell Mol Immunol (2014) 11(2):150-9. doi:10.1038/cmi.2013.59

83. Zhou L, Liu Z, Wang Z, Yu S, Long T, Zhou X, et al. Astragalus polysaccharides exerts immunomodulatory effects via TLR4-mediated MyD88-dependent signaling pathway in vitro and in vivo. Sci Rep (2017) 7:44822. doi:10.1038/ srep44822

84. Nie Y, Yang D, Trivett A, Han Z, Xin H, Chen X, et al. Development of a curative therapeutic vaccine (TheraVac) for the treatment of large established tumors. Sci Rep (2017) 7(1):14186. doi:10.1038/s41598-017-14655-8

85. Hossain DM, Pal SK, Moreira D, Duttagupta P, Zhang Q, Won H, et al. TLR9-targeted STAT3 silencing abrogates immunosuppressive activity of myeloid-derived suppressor cells from prostate cancer patients. Clin Cancer Res (2015) 21(16):3771-82. doi:10.1158/1078-0432.CCR-14-3145

86. Won H, Moreira D, Gao C, Duttagupta P, Zhao X, Manuel E, et al. TLR9 expression and secretion of LIF by prostate cancer cells stimulates 
accumulation and activity of polymorphonuclear MDSCs. JLeukoc Biol (2017) 102(2):423-36. doi:10.1189/jlb.3MA1016-451RR

87. Moreira D, Zhang Q, Hossain DM, Nechaev S, Li H, Kowolik CM, et al. TLR9 signaling through NF-kappaB/RELA and STAT3 promotes tumorpropagating potential of prostate cancer cells. Oncotarget (2015) 6(19):1730213. doi:10.18632/oncotarget. 4029

88. Vaisanen MR, Jukkola-Vuorinen A, Vuopala KS, Selander KS, Vaarala MH. Expression of Toll-like receptor-9 is associated with poor progression-free survival in prostate cancer. Oncol Lett (2013) 5(5):1659-63. doi:10.3892/ ol.2013.1204
Conflict of Interest Statement: The authors declare that the research was conducted in the absence of any commercial or financial relationships that could be construed as a potential conflict of interest.

Copyright $\odot 2018$ Ou, Lilly and Jiang. This is an open-access article distributed under the terms of the Creative Commons Attribution License (CC BY). The use, distribution or reproduction in other forums is permitted, provided the original author(s) and the copyright owner are credited and that the original publication in this journal is cited, in accordance with accepted academic practice. No use, distribution or reproduction is permitted which does not comply with these terms. 